\title{
JADE FORMS FROM ANCIENT CHINA
}

\author{
By Evelyn Tucker
}

The attraction of jade is two-fold: the nature of the material and the way it is used. The color, texture, and feel of jade are easily appreciated, but the symbolism of the motifs in which it is carved is an enigma to many of the stone's admirers. This article briefly examines some of the symbols used in iade carved in China, including an introduction to the religions on which much of this symbolism is based. By mastering these basic symbols and the philosophy behind them, collector and seller alike can gain greater understanding of the cultural and philosophical meaning of the art involved in a particular piece.

\section{ABOUT THE AUTHOR}

Ms. Tucker is a gemologist and course editor with the Home Study Department, Gemological Institute of America, Santa Monica, CA.

Acknowledgments: The author wishes to thank Mr. Edward Dominik for his advice, and Mr. Don Kay for information on the jade-carving industry. Thanks also to Michael Ross for his support and guidance. The photographs provided by Harold and Erica Van PeltPholographers (Los Angeles, CA) and Tino Hammid, of GIA Gem Media, are especially appreciated, as is the cooperation of the Asian Art Museum of San Francisco and the Los Angeles County Museum of Natural History.

01982 Gemological Institute of America
Tade has delighted the senses since it was first discovered. Like the early admirers of jade, today's collector is initially attracted to the appearance and feel of the stone; he is drawn to its color and texture, its smoothness and soft appearance. Soon, however, this attraction broadens into an interest in the material itself, in its history and uses.

Anthropologists and historians hypothesize that early people valued jade because they could, though slowly and laboriously, shape it into implements that were stronger and more durable than anything man had before he learned to forge metals (Hansford, 1968). Of all the stones that can be worked to suit the needs of man, jade is the most intractable. The same toughness that made jade implements so durable also made them difficult to fashion. As a result, early people simply ground their jade into convenient shapes. Later artisans maintained this tradition by following the contours of jade pebbles and boulders even when carving articles of great intricacy and sophistication (figure 1).

Although it is by no means common, jade is found in a number of areas of the world (most notably North and South America and Asial, and has been used and valued by a number of civilizations. The Chinese, however, perfected jade carving to a level unmatched by any other culture. Jade has played an integral role in their traditions since the beginning of recorded history (Whitlock and Ehrmann, 1949). No other gemstone is as closely tied to a major culture, as intricately interwoven with an aesthetic tradition. Although many people have wondered why jade so captivated the Chinese, no one has ever conclusively resolved this question. Perhaps part of the answer is that jade is well suited to the philosophies and religions of China; it seems to fit the Chinese cultural temperament. 


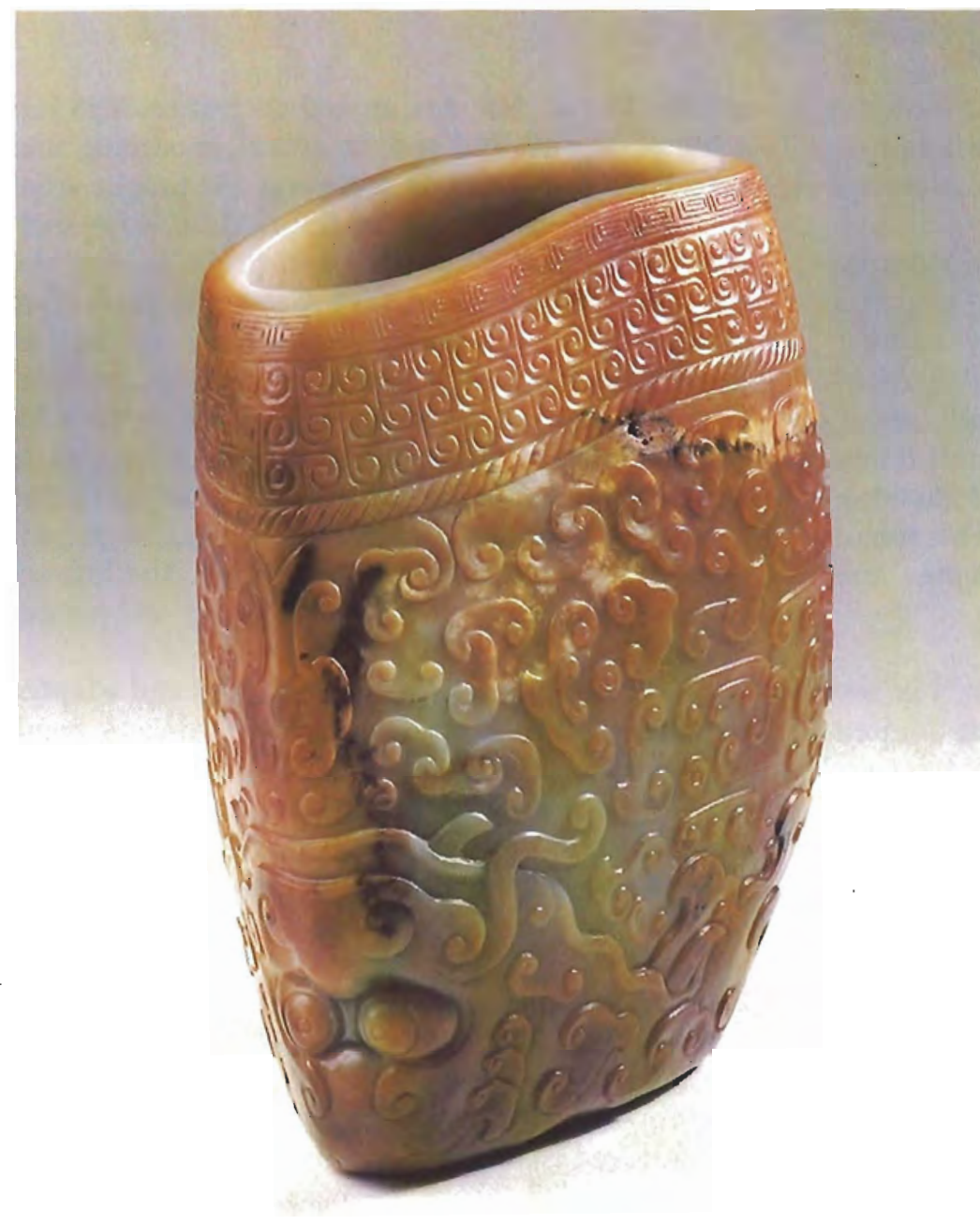

Figure 1. In planning and executing this piece, the artist used the outer "rind" and original contours of the water-worn pebble to produce a work of subtlety and sophistication. Jades seldom have dates on them, but this one has an inscription crediting it with "having spent a thousand autumns in the Khotan river," which is followed by the date 1785 A.D., the imperial signalure, and one of Emperor Chienlung's seals (d'Argencé, 1972).

Nephrite, Ch'ing dynasty (18th century A.D.), Chien-lung period, H. $5^{1 / 2}$ in. Courtesy of the Asian Art Museum of San Francisco, The Avery Brundage Collection.

\section{THE PHILOSOPHICAL AND RELIGIOUS FOUNDATIONS OF CHINESE ART}

Chinese philosophy, religion, and art are so closely interwoven that an appreciation of Chinese art requires at least a cursory examination of the philosophy and religions of this nation.

This survey covers only the three major religious and philosophical movements of ancient China. It is understood that any attempt to condense the art of a culture as ancient and sophisticated as that of China in a short essay only illustrates Western man's ethnocentricity. This overview, however, provides a few brush strokes of background for the discussion of motifs used in jade carvings from China.

The World View of Eastern Thought. Compari- sons reveal that art from the Eastern hemisphere differs greatly from art of the Western hemisphere. Differences in religion and symbolism come to mind, yet there is a more subtle and pervasive difference frequently overlooked or unappreciated by the Western intellect: in the culture, art, and philosophy of the West, man is at the center; in the East, man is one small part of a much greater whole.

Early Western man viewed the world from his perspective only: the earth was flat and the center of the universe. He even modeled his gods after himself. In his self-importance, he saw nature as his adversary and constantly sought to conquer it through brute force and strength of will.

The oriental approach is exactly the opposite. Especially in China, with its long history of Taoist teachings (as discussed below), man sought to em- 
ulate nature by observing its ways and following its example. As a result, no other culture is as successful in capturing the spirit of nature in its art (figure 2).

And what was man's place in the oriental scheme of things? Richard Gump (1962) suggests that you can answer this question by looking closely at a Chinese painting: "Where is man? There, that tiny figure sitting on that small bridge, in the midst of that vast landscape which represents the universe." This world view is incorporated in some way into all three of the major religions of China: Taoism, Buddhism, and Confucianism.

Taoism. Taoism (pronounced "dow-ism") is the oldest extant religion in China. It is an ancient form of nature worship. Tao in Chinese means "the way," "the road." Taoism is a way of intuition, of creativity, of searching for harmony with the forces of nature. Its most famous teacher, Lao $\mathrm{Tzu}$, is thought to have lived about 500 years before Christ. The Tao te Ching, a book of enigmatic poetry still studied by Taoist scholars today, is attributed to him.

With time, Taoism developed in a new direction. The older nature deities were overshadowed by a host of new divinities-spirits, ghosts, demons, and immortals-some of them borrowed from the new faith, Buddhism. All were eventually incorporated into a kind of folk religion tinged with magic.

Taoism was a primary force in the development of art in China. On one level, craftsmen and artists, using materials provided by nature, were often more successful working through intuition and experience rather than through rational analysis. On another level, scholars found their deepest insights in Taoist perceptions of nature and the nature of creativity. The search for an understanding of nature, and for a way of becoming part of the greater whole, a way of uniting with Tao, is the foundation of the Chinese artistic tradition.

Buddhism. Buddhism came to China from India at about the time of Christ. Initially it had little impact on Chinese culture, but by the second or third century A.D., it had reached its first peak of popularity. Buddhism has been a significant force in Chinese culture ever since (Willetts, 1958).

The historical Buddha was born in the sixth century B.C., probably in the region of India that is now Nepal. He was an Indian prince who left a life of wealth and ease to travel, meditate, and search for the causes of suffering. He taught what has come to be known as the middle way-neither the pursuit of desires and pleasure, nor the pursuit of pain and hardship. Gradually Buddhism evolved into a religion based on the premise that life is suffering which ends only in death, and that all life is caught up in an endless chain of reincarnation, traveling from birth through life, death, rebirth, and so on. This cycle continues until one reaches Nirvana, which has been described variously as the extinction of all desires, the knowledge of supreme reality, the state of perfect blessedness.

Over time Buddhism was adopted and adapted by the Chinese. And Buddhist subjects were wrought in a characteristically Chinese style. Thus we see Buddha, or any of a number of other Buddhist figures, in Chinese dress, adopting Chinese poses, and surrounded by Chinese landscapes.

Confucianism. Confucius, a Chinese scholar and teacher, was also born in the sixth century B.C. Although he was a contemporary of Lao Tzu, his teachings differed radically from those of Taoism. He believed that cultivated men, trained in ethics and aesthetics, were the best hope for a stable government. He taught that respect for one's elders, for the wisdom of early rulers, and for ritual observance would promote the welfare of humanity. These ancient Chinese teachings, which he and his disciples codified and collected into several volumes, have been a shaping force in Chinese culture for 2,500 years.

Confucius's tolerant, scholarly, well-mannered approach to life exercised a profound influence on Chinese art. His philosophy of the Golden Mean, developed in his work the Chung Yung, or Doc-

Figure 2. This carving is an outstanding example of the Chinese use of color and symbolism in jade. The peach is a symbol of immortality; the bats denote happiness; the butterflies, immortality; and the silkworm, industriousness. Jadeite, 19 th century, 478 in. by 4 in. Courtesy of the Crystalite Corporation. Photograph 1981 Harold erica Van PeltPhotographers, Los Angeles, CA. 

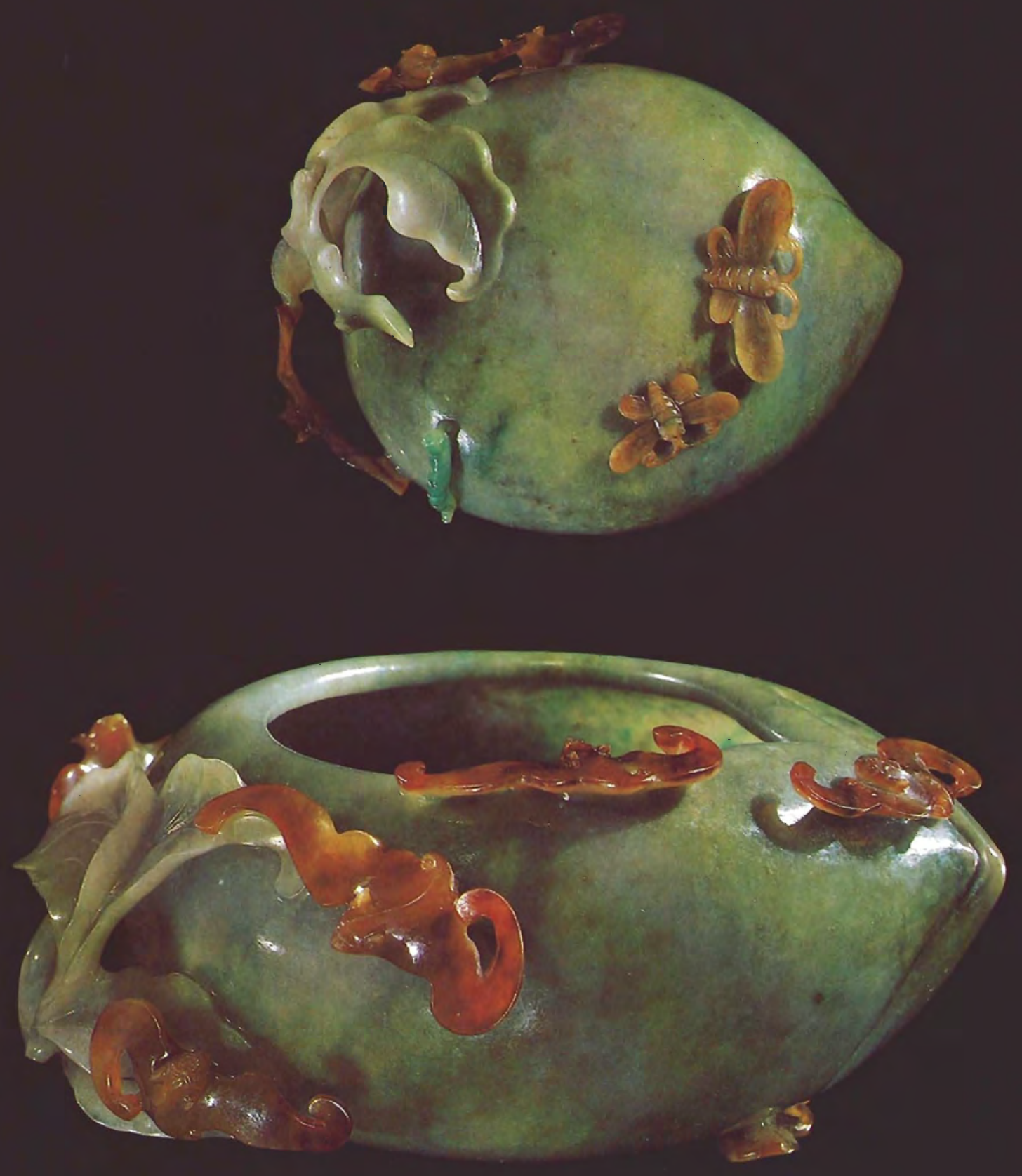
Figure 3. Two t'ao t'iehs (monster masks) appear on the front of this covered urn. Both masks are split by the ridge running down the front of the piece. The upper mask is highly

stylized, so that only the eyes are easily

recognizable. The lower t'ao t'ieh is more conventional: its eyes, eyebrows, and flaring nostrils are clear. Nephrite, late 19th century, H. 133/8 in. Courtesy of the Los Angeles County Museum of Natural History. Photograph by Tino Hammid, GIA Gem Media.

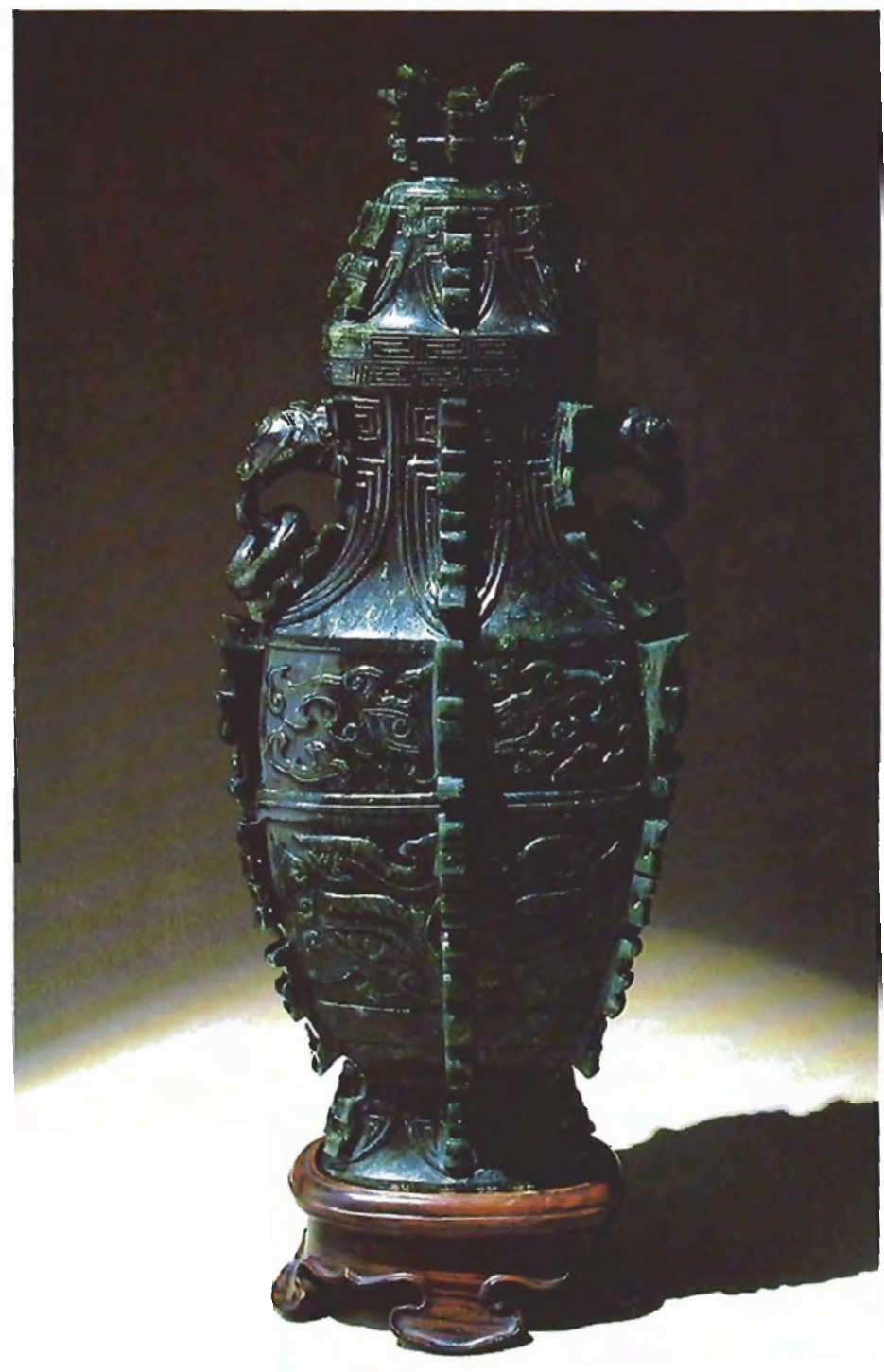

trine of the Mean, advocated a love of learning and knowledge so that one might become a "superior man." Moderation in everything was central to his philosophy. The Chinese artist followed the doctrine of the mean. The philosophy of neither too much nor too little led him to seek a perfect balance in his use of detail, proportions, textures, and colors.

Confucianism also affected Chinese art by fostering an appreciation of the culture's ancestral heritage. Because Confucius and his followers taught respect for one's elders, for tradition, and for the wisdom of the ancestors, many early artistic motifs were used long after their original meanings were lost. In some instances, these are among the most pervasive forms in Chinese art. The t'ao t'ieh is one such form.

\section{T'AO T'IEH}

Of all the emblems ever used in Chinese art, the most constant in form and most widely used is a compound, mask-like design known as the t'ao $t^{\prime}$ ieh (figure 3). It is both one of the oldest and one of the least understood of the ancient motifs (Nott, 1947).

We do know that Sung dynasty $1960-1279$ A.D.) art critics labeled this already ancient emblem the t'ao t'ieh, or "glutton," inferring that it was orginally meant as a symbol of greed or lust and used as a waming against these vices. Their theory, however, is no longer taken seriously as an explanation for the origin of the $t^{\prime}$ ao $t^{\prime}$ ieh. For one thing, it is inconceivable that the Chinese would have insulted their ancestors, their minor deities, or their guests at official banquets by 
warning them against eating or drinking too much (Burling and Burling, 1953).

Described as a "gluttonous ogre with a fang projecting on each side," the mask might be a representation of "the all-devouring storm god of the Chinese, with a background of clouds" (Laufer, 1946). Laufer supports this theory with his observation that "the t'ao t'ieh always appears on a background of meanders emblematic of atmospheric phenomena...." However, he also cites another expert (Hirth), who proposes that the early $t^{\prime}$ ao $t$ 'ieh was based on the features of the Tibetan mastiff. This is possible since the Chinese domesticated the dog in ancient times and held it in high esteem.

The $t^{\prime}$ ao $t^{\prime}$ ieh has also been identified as a dragon, but Pope-Hennessey (1923) points out that since the $t^{\prime}$ ao $t^{\prime} i e h$ and the dragon sometimes appear side by side on the same object, this explanation is unlikely. Instead, she suggests that the $t^{\prime}$ ao $t^{\prime}$ ieh was derived from the face of a tiger. This theory is more plausible than most, since the tiger is an ancient and ominous figure in Chinese art. It is also consistent with the appearance of the t'ao t'ieh and dragon on the same carving, since Chinese mythology has traditionally grouped the tiger and the dragon together. The tiger symbolizes the West and autumn; and the dragon, the East and spring. The winds were said to follow the tiger; and the rains, the dragon (Nott, 1947). It has also been suggested that the $t^{\prime}$ ao $t^{\prime}$ ieh is a diagram which ancient Chinese healers used when diagnosing and discussing pain with their patients (Nott, 1947).

Because of its antiquity, the $t^{\prime}$ ao $t^{\prime}$ ieh is probably Taoist in origin. Since it can be made up of any collection of natural forms grouped symmetrically to suggest a mask, it is perfectly suited to the Taoist perception of patterns within patterns in nature and the universe. As such, it is a wonderfully versatile decorative device whose long life stems, at least in part, from its ability to be modified and used in a variety of ways without becoming repetitious. It can be strong, bold, and dominant, or faintly and delicately suggested. Today, the t'ao t'ieh is used as an emblem of cultural origin, an elegant testimony to an ancient aesthetic heritage.

\section{THE PI}

Although much has been written, little is understood about the origin and meaning of the pi (pro- nounced "bee"), a flat, circular disk with a hole in the center. Early forms were plain and roughly finished. As the art of carving progressed, however, the pi was first covered with relief designs, and later carved as ornate, highly stylized sculpture (figure 4).

Undoubtedly Taoist in origin, the pi has been used in ritual worship since the beginning of recorded history. In writing about the pi, jade authorities have suggested that it stood for everything from a musical instrument to the flywheel of a drill (Willetts, 1958). The most popularly accepted interpretation, however, is that the pi represents heaven. The Book of Rites /Chou dynasty, $1122-256$ B.C.) lists it as the first of the six ritual jades: "With a sky-blue pi, worship is paid to Heaven."

Gump proposes that the pi stands for, among other things, the sun disk, or the sun shining through the vault of heaven, or heaven itself. As he suggests, we have only to put ourselves in the place of the early Chinese looking up into the sky to understand this explanation. That the ancient graph for sun was written as $\odot$ further corroborates this theory (Willetts, 1958). Whatever its origin, for thousands of years the pi has been used as a symbol of heaven and is so used today.

\section{THE DRAGON}

Created in ancient Babylonia, mankind's most pervasive mythical invention moved, both literally and figuratively, in opposite directions, toward the West to become a symbol of evil, and toward the East to become a symbol of beneficence. Today it is known the world over as the dragon (Leach and Fried, 1972).

Actually, as is the case with other ancient symbols, the true origin of the dragon is open to conjecture. That it is mankind's most common mythical animal, one that is found in almost all cultures, has produced endless rounds of speculation and little agreement among authorities. Perhaps it is a Jungian archetype, an element of the subconscious common to all men regardless of culture. Or perhaps, as suggested above, it had one birthplace in mythology and spread as travel and trade increased throughout the world. A combination of these two theories probably explains the dragon's pervasiveness. Even if it had one birthplace, the dragon myth could hardly have spread and taken hold unless it satisfied some basic need in the human psyche. 


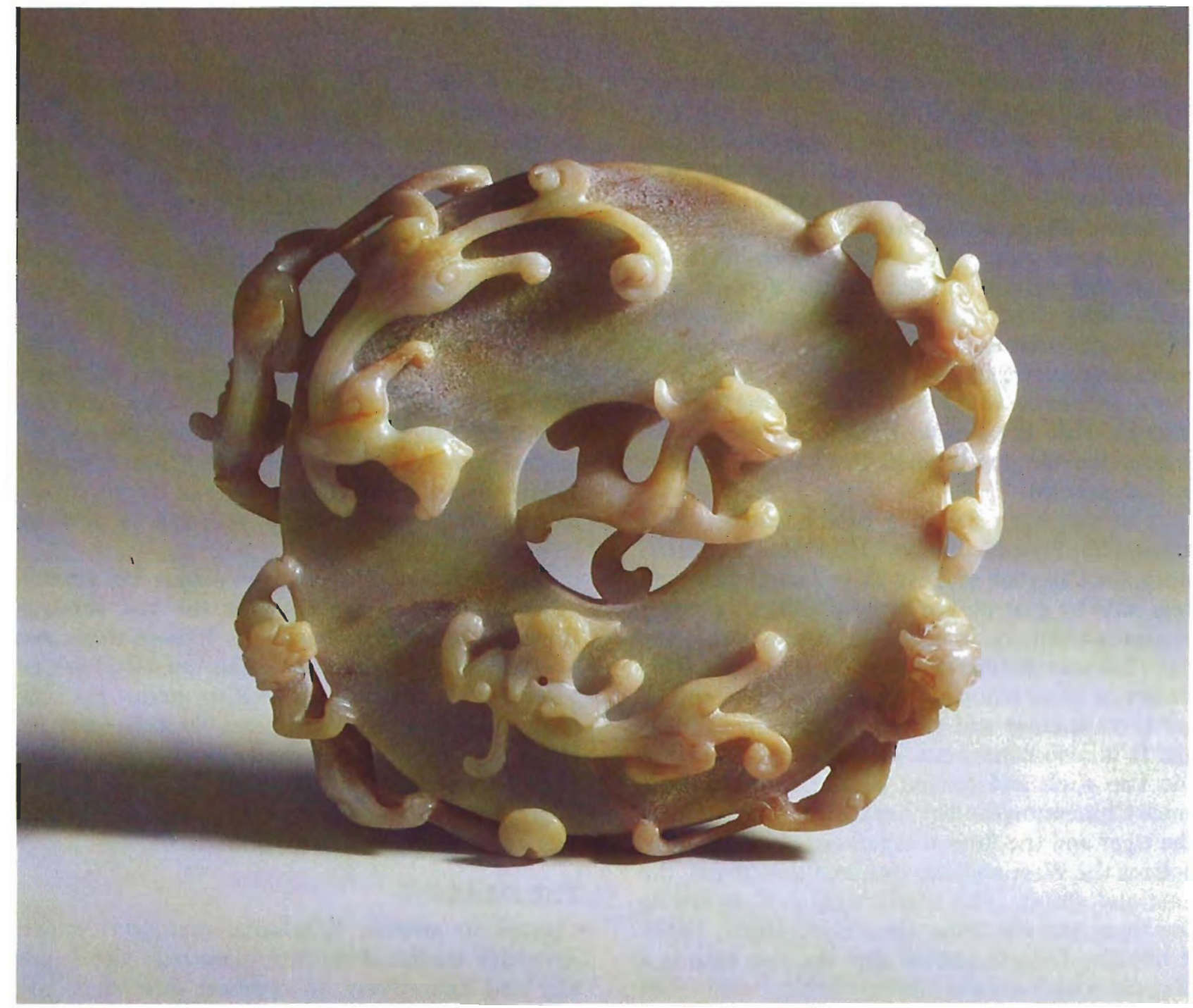

Figure 4. Nine lithe, almost cat-like, ch'ih dragons scamper around and through this pi.

The lack of scales and claws, the sinewy body, and the playful stance characterize this type of dragon. Nephrite, late medieval or early Ming period (14th-16th century A.D.), Diam. 51/2 in. Courtesy of the Asian Art Museum of San Francisco, The Avery Brundage Collection.

Less esoteric scholars remind us of the existence of prehistoric dinosaur bones and suggest that there is an obvious connection between early dragon myths and the discovery of the first of these bones (Leach and Fried, 1972). Such discoveries may or may not have produced the dragon myth, but they undoubtedly contributed to its proliferation.

In discussing the origin and development of the dragon myth in China, scholars frequently mention the snake worship of India, citing the Indian influence on Chinese culture, most notably the influx of Buddhism at about the time of Christ. According to Nott (1947), in Chinese translations of Buddhist writings the Indian term naga ("snake") is frequently rendered lung ("dragon"). However, the dragon existed before Buddhism came to China and probably before Buddhism began; thus, while snake worship might have influenced the development of the dragon myth, it is unlikely to have been its source.

There are many different kinds of dragons in Chinese mythology. All are benevolent creatures associated with nature and the elements. They control the wind and, more importantly, the rain that nourishes the crops.

The least fearsome are the chi'ih, or immature, dragons. These are usually portrayed as 


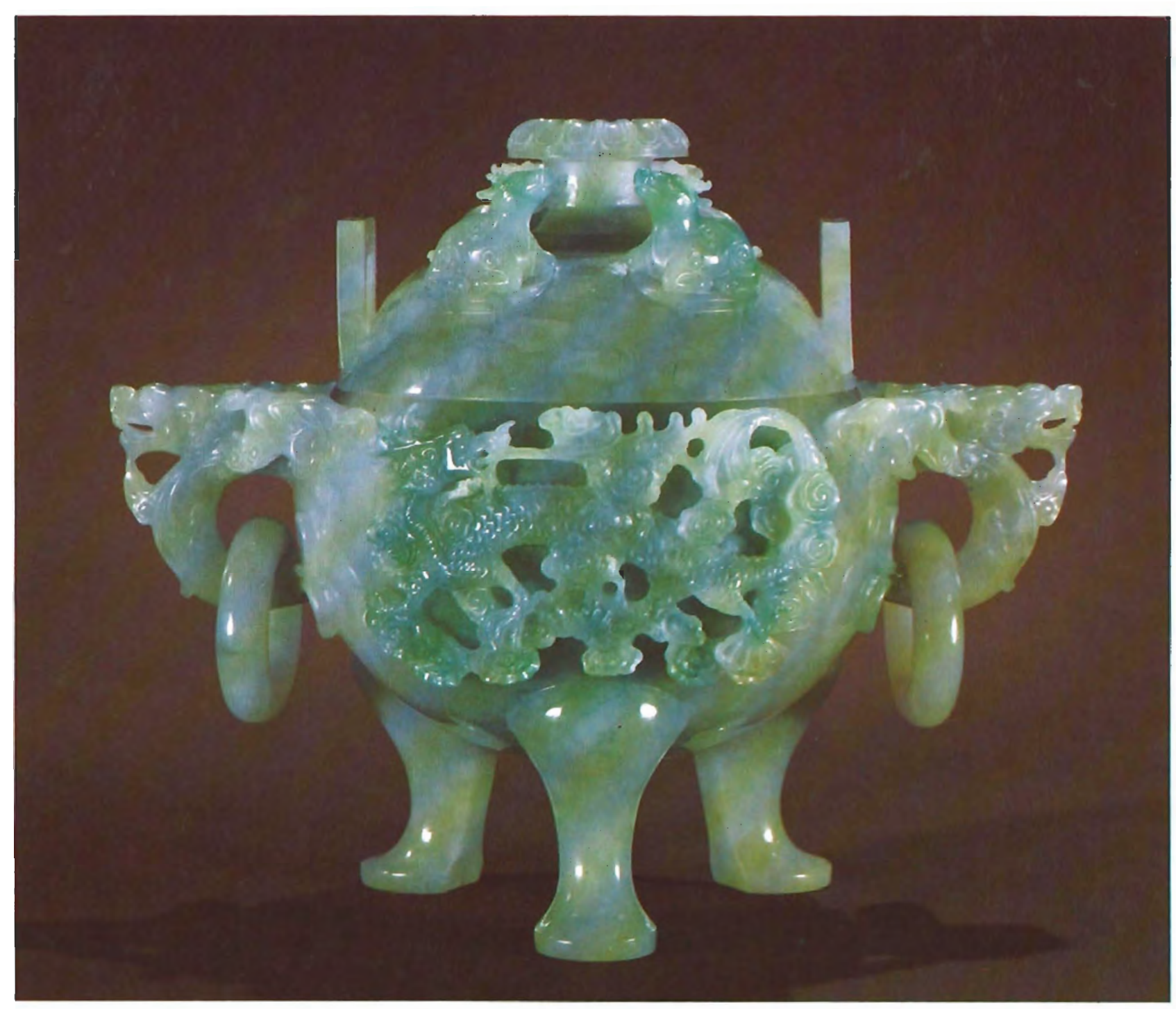

Figure 5. A fire-breathing dragon is carved in high relief on this vessel. Jadeite, late 19th century (3), H. 5 in. Courtesy of the Crystalite Corporation. Photograph 1981 Harold \& Erica Van Pelt-Photographers.

clinging, lizard-like, or in some instances almost cat-like, reptiles with clawless feet and a split tail (again, see figure 4). The chi'ih dragon is particularly beneficial, said to have guardianship over mortals (Nott, 1947).

Water dragons are characterized by sinewy, fish-like bodies, also with long split tails. In Chinese mythology, they have dominion over the oceans and rivers (Nott, 1947). It has been suggested that the dragon was modeled after the alligator (Gump, 1962); the scales on the water dragon support this theory.

Regardless of its origin, the development of the dragon myth in China was remarkable. In no other culture do we find the profusion of types and styles of dragons (figure 5), and nowhere is the dragon as important as it is to the Chinese. Because this myth has existed for such a long time and is so closely associated with nature and the elements, the dragon of Chinese mythology is probably Taoist in origin.

\section{THE FO DOG}

Although in its conventional form it resembles a pekingese more than anything else, the dog of Fo is actually a Buddhist lion (figure 6). Since fo dogs (pronounced "foo," as in "food") came to China with Buddhism, they are not seen in Chinese art earlier than the Han dynasty (207 B.C.-220 A.D.).

In Buddhism, the lion is the defender of the law and the guardian of sacred buildings. Far from being intimidating, fo dogs are usually portrayed 
Figure 6. Two elaborate antlered dragons hold loose rings on the side, and a fo dog snarls from the top of

this incense burner. A low-relief

free-form carving decorates the front. Nephrite, Date (?), H. 6-7/10

in. Courtesy Los Angeles County Museum of Natural History. Photograph by Tino Hammid, GIA Gem Media.

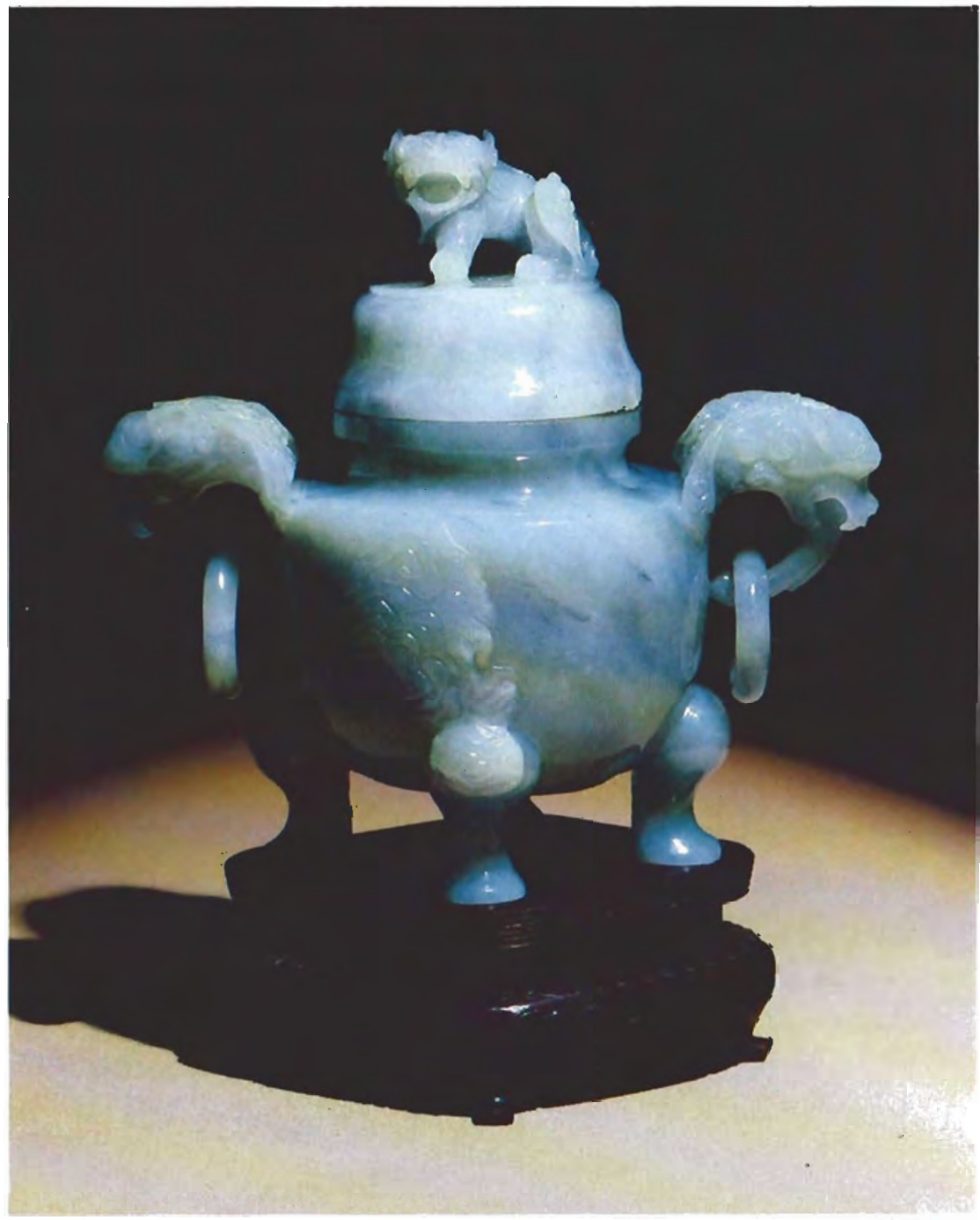

as small, playful lions and are frequently shown with a brocaded ball that represents the Jewel of the Law. In their capacity as guardians, they are often placed at the entrances of buildings or on the corners of roofs. Fo dogs may be standing or sitting, with their heads up or elegantly curved back, jaws open, and manes and brows represented by spirals.

\section{JADE MOUNTAINS}

The largest and most famous jade mountains were carved during the reign of Ch'ien-lung; who ruled China from 1736 to 1795 . The empire was secure under Ch'ien-lung; trade flourished, the economy was strong, China was wealthy. Not only was Ch'ien-lung an able statesman and ruler, he was also a creative thinker and a patron of all artistic endeavors. His reign was an age of creative freedom and artistic accomplishment.

During the reign of Ch'ien-lung, jade carving reached "an apex of perfection and refinement never touched before or since" (Burwell, 1948), as figures 1 and 3 illustrate. In a field where agreement among authorities is conspicuously absent, all are unanimous that as a group $\mathrm{Ch}^{\prime}$ ien-lung jades are the finest jade carvings ever produced. Consequently, there is a tendency to label all fine jade carvings as Ch'ien-lung even though they may have been produced before or after that period.

Jade mountains are mentioned in Chinese literature as early as the Yuan dynasty (1260-1368 A.D.). According to d'Argencé (1972), though, none has been dated with any certainty prior to the Ch'ing dynasty (1644-1912 A.D.).

Religious motifs predominate in jade carvings, and throughout most of China's history carvers freely chose the religious themes they used. As a result, different pieces from one workshop might be inspired by any of China's religions. Most jade 


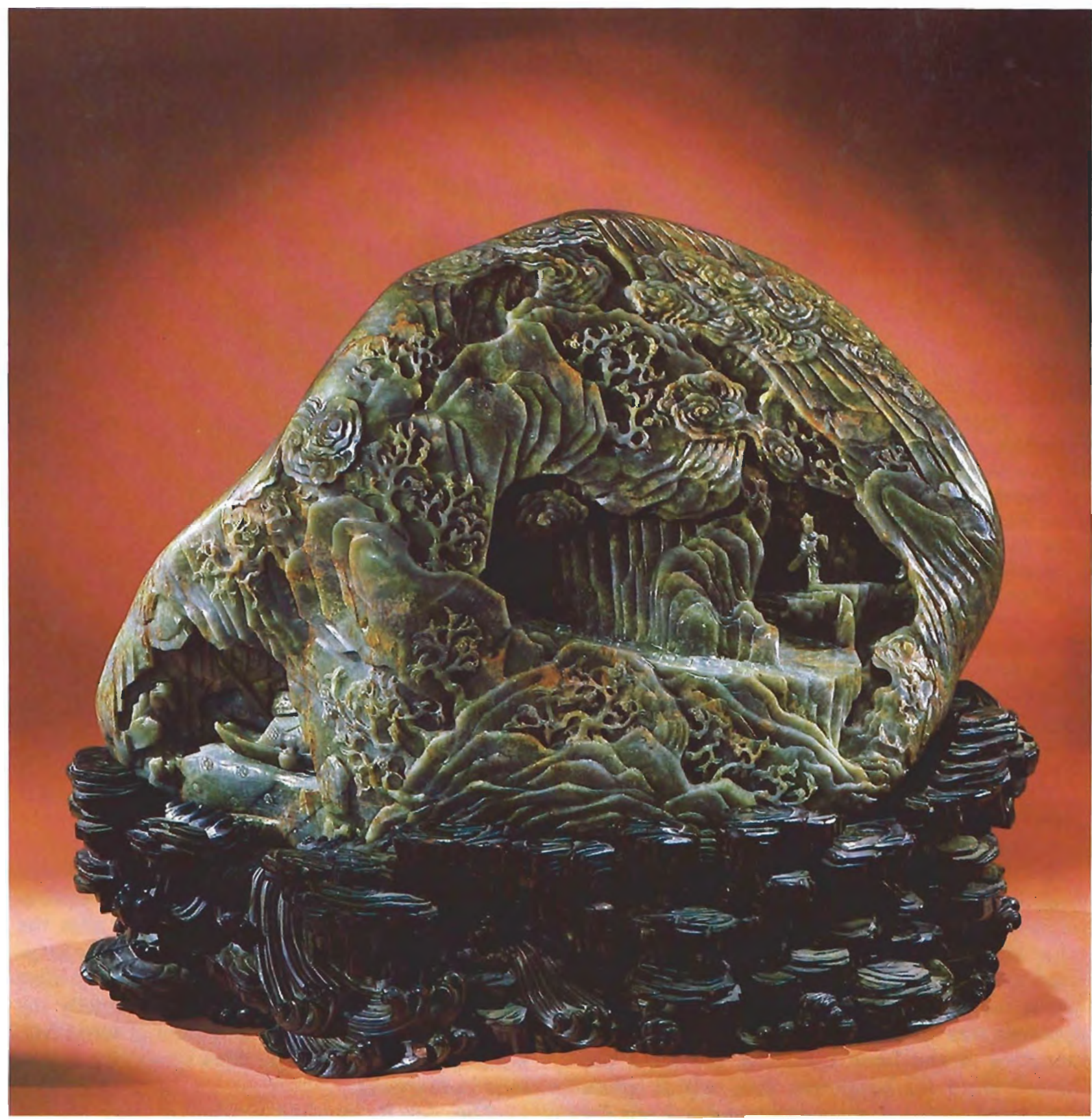

Figure 7. Although highly ornate, the trees and clouds on this jade mountain harmonize with the contours of the original stone and illustrate the oriental desire to emulate nature. The lone human figure symbolizes man's place in the overall scheme of the universe. Nephrite, date (!), W. 24 in. Courtesy of the Crystalite Corporation. Photograph 1981 Harold \&) Erica Van Pelt-Photographers, Los Angeles, CA.

mountains are naturalistic renderings of scenes from Buddhism, Confucianism, or Taoism. The Taoist love of nature is, however, an underlying theme in all jade mountains regardless of their overt subject matter (figure 7). Jade mountains embody the Chinese respect for nature and the Taoist desire to seek refuge in the tranquility of the country.
THREE TAOIST SYMBOLS: THE BAT, THE BUTTERFLY, AND THE PEACH

The Taoist love of nature and the Chinese love of symbols combined to transform a number of unlikely animals and plants into auspicious emblems used in small carvings or as decorative motifs on larger pieces. 


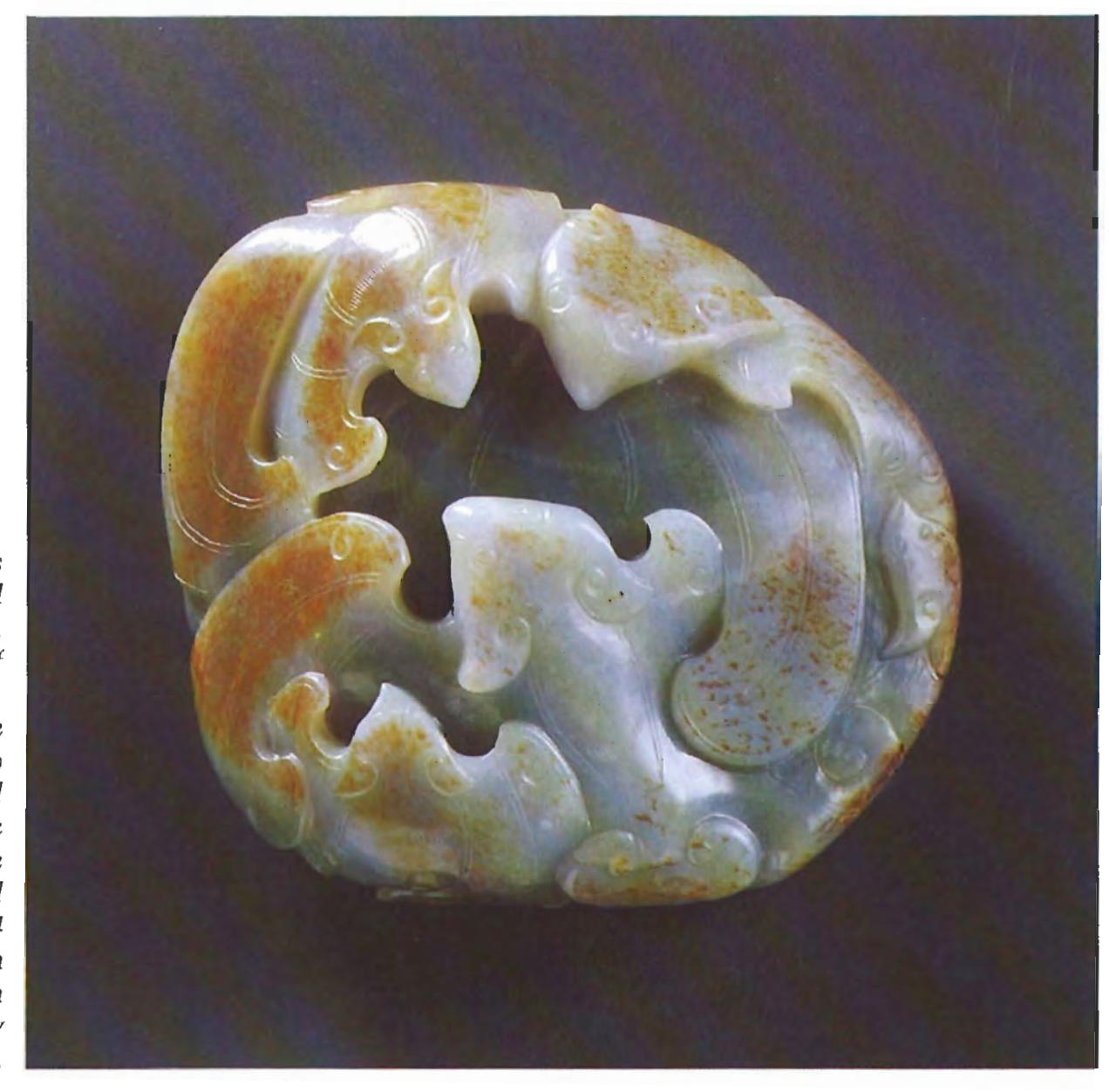

Figure 8. Five bats symbolize happiness and the five blessings: old age, health, wealth, love of virtue, and a natural death.

The two larger and three smaller bats might also represent the family and

a wish for domestic happiness. Nephrite, late Ming-early Ch'ing period (17th century A.D.), W. 4

in. Courtesy of the Asian Art Museum of San Francisco, The Avery Brundage Collection.

The butterfly is a symbol of immortality (again,

In most countries, the bat is maligned and unloved, but in China it is a symbol of happiness and long life. The Chinese are renowned punsters, and at times their puns have become well-established symbols and art motifs (d'Argencé, 1972). This is the case with the bat; its use to signify happiness was not derived from the natural characteristics of the little marauder but from the Chinese word for happiness, fu-i, which when pronounced with a slightly different emphasis denotes a bat. When depicted in groups of five, the bat symbolizes the five happinesses or blessings: old age, health, wealth, love of virtue, and a natural death (see figure 8 and refer back to figure 2).

The Chinese wedding ceremony includes the prescription that the bride and bridegroom each drink three cups of wine in succession (Nott, 1962). The vessels used in the ceremony are frequently decorated with such auspicious symbols as bats, butterflies, and peaches. In this instance, the bat is associated with matrimony; it is a common motif on wedding presents and symbolizes the wish for a long and happy marriage. see figure 2). In ancient times, jade butterflies were buried with the dead in the hope that the deceased would awaken to an afterlife in the same way that a butterfly emerges from its cocoon after a period of dormancy (Nott, 1962). Gradually the butterfly has evolved into a symbol of longevity. When used in pairs, butterflies symbolize happiness in marriage.

The peach, another symbol of immortality (figure 2), has origins that are even more obscure. According to early Taoist mythology, the peach was a talisman in the quest for everlasting life. Legend has it that $\mathrm{Ho} \mathrm{Hsien} \mathrm{Ku}$, the only female of the eight Taoist immortals, ate one of the peaches of immortality and so achieved eternal bliss (Nott, 1962). Other religious figures are also frequently depicted holding or carrying peaches.

Unlike many other cultures, the Chinese were remarkably tolerant of religious differences. While there was religious persecution from time to time, for the most part the three dominant religions of China co-existed peacefully, even borrowing sym- 


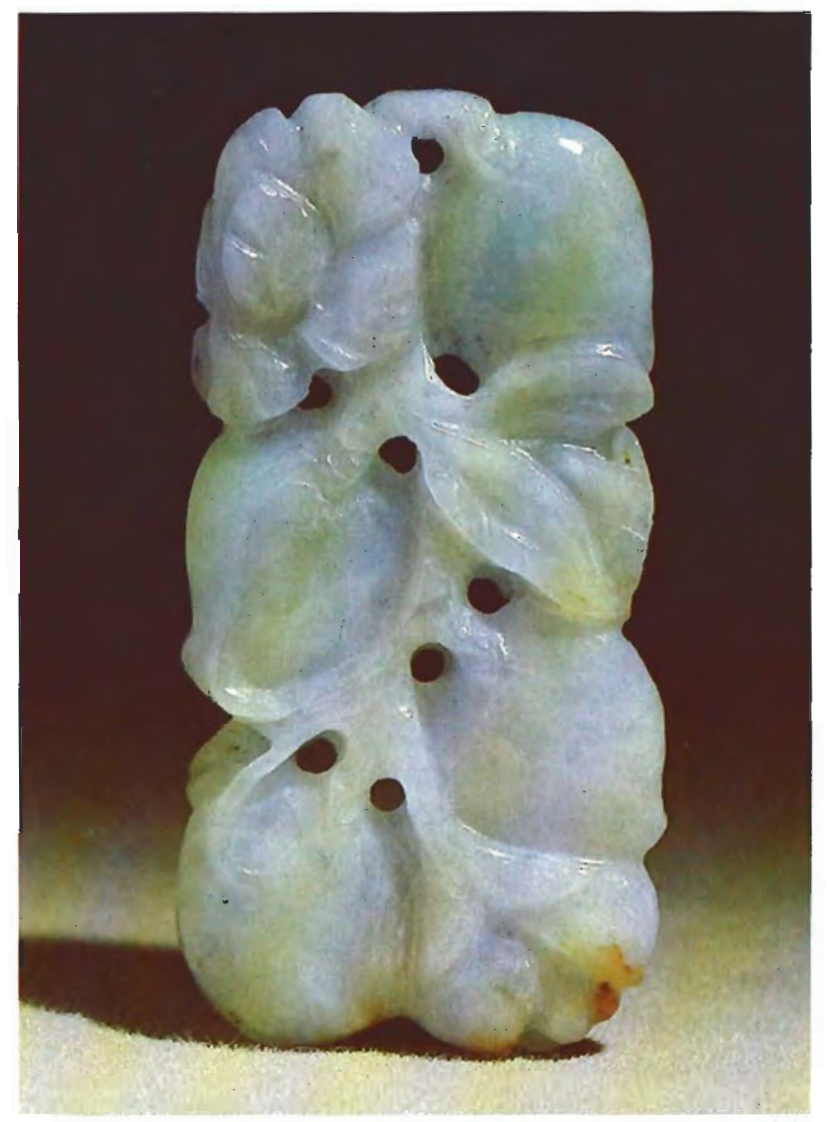

Figure 9. Small, slightly flattened peaches are frequently carved for use as pendants. They symbolize the wish for a long and happy life. Jadeite, Modern, H. 2 in. Photograph by Tino Hammid, GIA Gem Media.

bols from one another. For example, the Buddhist saint Kuan Yin is often depicted with the Taoist peach of immortality. Today, small, slightly flattened, almost heart-shaped peaches, carved singly or in bunches, are worn as pendants to symbolize the wish for a long and happy life (figure 9).

\section{IADE CARVING TODAY}

Jade carving is an ancient art. Not only were the Chinese carving jade before the fall of Troy lapproximately 1184 B.C.), but they were also using some of the same motifs then that they use now. For example, some of the more comprehensive collections of early carvings contain examples of pi's, t'ao t'iehs, and dragons from the late Shang (1766-1122 B.C.) and early Chou (1122-256 B.C.) dynasties.
Today, in an age characterized by space travel, micro chips, and computers, the Chinese are still carving jade. A large community of hardstone carvers following the Chinese tradition flourishes in Hong Kong. Smaller carving centers are scattered throughout the Far East. In the United States, some individual carvers are making names for themselves on both the East and West Coasts. The People's Republic of China produces hardstone carvings both for export and for their domestic market. Recent reports indicate that they are attempting to further revitalize their carving industry by offering tax incentives and other inducements to Hong Kong carvers who set up shops and teach in mainland China (Don Kay, personal communication).

Modern tools and methods have changed the jade carver's art. Carvings that once would have taken years can now be finished in weeks or months. The great potential for jade carving lies in blending the old and the new. A skilled and artistic carver who combines contemporary tools with the artistic heritage developed in China over the last 4,000 years can create a work of art to rival any produced in the history of jade carving.

\section{REFERENCES}

Burling J., Burling A.H. (1953) Chinese Art. Crown Publishers, New York, NY.

Burwell W.B. (1948) "Exhibition of Chinese Jades-OACLondon." Oriental Art, Autumn 1948, p. 157.

d'Argencé R.L. (1972) Chinese Jades in the Avery Brundage Collection. The de Young Museum Society and Patrons of Art and Music for the Center of Asian Art and Culture, Japan.

Gump R. (1962) Jade: Stone of Heaven. Doubleday \& Company, Garden City, NY.

Hansford H.S. \{1968). Chinese Carved lades. New York Graphic Society, Greenwich, CT.

Laufer B. (1946) Jade, a study in Chinese Archeology and Religion. P.D. \& Ione Perkins, South Pasadena, CA.

Leach M., Fried J. (1972) Standard Dictionary of Folkore, Mythology and Legend. Funk \& Wagnalls, New York, NY.

Nott, S.C. (1947) Voices from the Flowery Kingdom. E.L. Hildreth \& Company, Brattleboro, VT.

Nott S.C. (1962) Chinese Jade Throughout the Ages. Charles E. Tuttle Company, Rutland, VT, and Tokyo, Japan.

Pope-Hennessey U. (1923) Early Chinese Jades. Frederick A. Stokes Company, New York, NY.

Whitlock H.P., Ehrmann M.L. (1949) The Story of Jade. Sheridan House, New York, NY.

Willetts W. (1958) Chinese Art. Richard Clay \& Company, Great Britain. 